\title{
TOWARDS A CONDUCIVE INVESTMENT CLIMATE WITHIN ECOWAS: THE CASE FOR THE AMENDMENT OF SECTIONS 27 AND 28 OF THE GHANA INVESTMENT PROMOTION CENTRE ACT 865 OF 2013
}

\author{
Francis Kofi Korankye-Sakyi ${ }^{1}$ and Kweku Attakora Dwomoh ${ }^{2}$
}

\begin{abstract}
ince the independence of Ghana, she has been at the forefront of the integration of the African continent and for that matter the West African sub-region. Many developing countries are moving towards adapting to international and regional arrangements to enhance their relevance and leverage on trade and investment opportunities for their socio-economic development. Ghana is considered as having one of the safest and most conducive investment climates for doing business in Africa. This stride is attributed to its enduring democratic and legislative environments. The gains made so far in this respect seem to be losing its steam due to the far-reaching conflicting provisions that exist between the Ghana Investment Promotion Centre Act 865 of 2013 which regulates the investment activities in Ghana and that of the Economic Community of West African States (ECOWAS) provisions in the Protocol on Free Movement of People, Goods and Services. Through a qualitative desktop analysis of the legal literature available, this paper argues that some provisions of Act 865 specifically sections 27 and 28 of Act 865 are in violation of Ghana's obligation under the ECOWAS protocols. On the backdrop of article 36(4) of the 1992 Constitution of the Republic of Ghana, this article identified such provisions in Act 865 and proposes an amendment to conform with the Community laws of ECOWAS to engender socio-economic development and political security of the subregion.
\end{abstract}

Keywords: GIPC Act 865 of 2013; trade and investment; Ghana; ECOWAS; economic development.

1 B. Ed, LL. B, LL. M, MA: Lecturer, Faculty of Law, University of Cape Coast, Ghana 2 LLB, QCL, LLM: Lecturer, Faculty of Law, University Profesional Studies, Accra, Ghana \& Private Legal Practitioner. 
Towards a Conducive Investment Climate Within Ecowas: The Case for the Amendment of Sections 27 and 28 of the Ghana Investment Promotion Centre Act 865 of 2013

\section{Introduction}

Investment laws point an investor to how and by which means he can apply his capital into an investment in a country; they direct the investor(national and non-national) to his rights, privileges, duties and obligations in the host country; they provide the general regulatory requirements governing such form of investment; and they assure security of investments. Since Ghana's independence, Ghana has been at the forefront of the integration of the African continent with one of the safest and conducive investment climates for doing business. ${ }^{3}$ This has been the result of its democratic and profound legislative environment. The foremost legialstive instrument for regulating investor activities in Ghana is the Ghana Investment Promotion Centre Act (GIPCA), 2013 (Act 865) 4 as an enabling instrument to the demand of the 1992 Constitution of the Republic of Ghana (the Constitution). ${ }^{5}$

However, there is far-reaching conflicting provisions that exit between Act 865 and that of the ECOWAS protocol on free movement of people, goods and services. ${ }^{6}$ This article identifies such provisions in the Act 865 and argues for an amendment to conform with the ECOWAS' protocol to engender socio economic development and political security of the subregion.

Within the international milieu of investment, many countries are moving towards securing international and regional arrangements to enhance their relevance and leverage on trade and investment opportunities for their socio-economic development.

Bradlow agrees that:

Every dynamic social system's adaptive capacity is finite. Eventually, the ability of the system's legal and institutional arrangements to adapt to the changing operational context is exhausted. At this point, unless the system is significantly reformed, it begins losing its legitimacy and efficacy. ${ }^{7}$

Flowing from this, it is posited that the current legal framework underpinning Ghana's investment activities has not reached its finite limit yet to warrant non-negotiable engagement for review. To this end, it requires adapting to changing circumstances of the day to defend the legislative legitimacy and relevance of the current GIPCA within the international economic order. Bradlow contends that the challenge to reforms in global economic governance lies

3 Sanusi and Adu-Gyamfi 2017 JHS 599-608.

4 Section 3 Act 865.

5 Article 36(4) of the Constitution.

6 Supplementary Protocol A/Sp.2/5/90 on the Implementation of the Third Phase (Right of

Establishment) of the Protocol on Free Movement of Persons, Right of Residence and Establishment.

7 Bradlow 2018 IORJ 213-236. 
with the lack of political will to advertise for the needed changes to institutional legislations. ${ }^{8}$ It is indeed a dilemma for many governments in the sub region to muster this political will to give up their domestic interests for supranational alternatives. ${ }^{9}$ The absence of this is a recipe for crises in international relation. ${ }^{10}$

The unfriendly legal environment in most African countries have served as a major blockade to the economic integration of the continent. The recent impasse between the Ghanaian business community and its major trading neighbour, Nigeria on retailing in the respective countries is deemed as a consequence of these conflicting legislations upon which the perpetrators of the atrocities take their motivation. ${ }^{11}$

The need for economic integration through regional and sub-regional protocols cannot be over-emphasised. Oloruntoba, Nshimbi et al conceptualised integration as "the cooperation among sovereign states, which leads to the removal of restrictions to facilitate mobility." ${ }^{\prime 2}$ It is also described as "a process of both deepening and widening relationships amongst actors." ${ }^{13}$ Regional integration is considered as a cooperation through the voluntary surrendering of individual national sovereignties of nation-states for supranational institutions to achieve a better development in order to better the condition of lives of their people. ${ }^{14}$

It is confirmed that "existing literature has investigated the benefits and effectiveness of the protocol in the West African Sub-region." ${ }^{15}$ Key amongst these reasons include the fact that in majority of the countries, the major primary products for export are basic agricultural produce and unrefined mineral resources that do not support robust international trade. ${ }^{16}$ The domestic markets in the subregion are smaller with substantial structural deficits; weak physical infrastructure, inadequate capacity building tools, financial sector deficiencies,

8 Bradlow (n 7) 213.

9 Aryeetey OECD Development Centre Working Paper 2001 1-45.

10 Ghana is now involved in brawl with Nigeria which involves each country's cross-border traders pointing to harassments and abuses by opposing citizens for engaging in one sort of trading activity or the other. Nigeria has escalated the confrontation by closing its borders to neighbours in the sub-region to prevent "illegal traders" so to speak till 2020.

11 GhanaWeb 2019 https://www.ghanaweb.com/GhanaHomePage/NewsArchive/Nigeria-s-bordersto-remain-closed-until-end-of-January-795921 accessed 27 October 2019; rfi 2019 http://www.rfi.fr/en/ africa/20191101-nigerian-owned-shops-ghana-kumasi-forced-close-traders-union-borders-closed .See also BBC 2019 https://www.bbc.com/pidgin/tori-48682143 accessed 28 October 2019; GHOne TV 2019 https://www.facebook.com/156439147743926/posts/257668286320988.

12 Nshimbi, Moyo and Oloruntoba 2018 Africa Insight:4.

13 Opanike and Aduloju $2015 \mathrm{~J}$. Civil and Legal Sciences 154.

14 Opanike and Aduloju (n 13).

15 Opanike and Aduloju (n 13).

16 ljeoma 2007 Africa Insight 62. 
underdeveloped manufacturing sector ${ }^{17}$ which largely fall on imported commodities to meet the basic needs of the population. Weak infrastructure coupled with non-conducive legal environment has derailed the progress in investment opportunities in the subregion. The core rationale for integration is to promote the free flow of goods, services and people across borders. ${ }^{18}$ It is a conduit to facilitate factors of production across boundaries and galvanise inter-border trading. The objective to achieve mutual prosperity for the nations must be contingent on the combination of both the political and economic prospects of the subregion. ${ }^{19}$

It has been emphasised that some African countries through their laws have created the opportunity for the violation of the rights of cross-border traders. ${ }^{20}$ This is the situation in which Ghana has inadvertently created, thereby putting at risk the enjoyment of the rights of migrants under the ECOWAS protocol. ${ }^{21}$

\section{Historical brief on Ghana's investment laws}

Historically, Ghana's investment policy and regulations directions have metamorphosised under different regimes of governments; all in an attempt to position the country to compete and attract the needed investment to its fold. These changes do not offend the international norm on policy environment regarding trade and investment. Cross-border investment laws go under constant reviews in various countries to adapt to a new economic and international order in so far as it is aimed at influencing the overall investor decisions towards that country. ${ }^{22}$ This article is not about the history of Ghana's investment laws but in the preceding sections, we shall provide a background to the Act 865 to lay a foundation on how far Ghana has come with its investment legal underpinnings. We shall group the historical journey into two phases; the non-liberal investment era: 1963-1994 and the liberal investment era 19942013 for the purposes of clarity.

\section{The non-liberal investment era: 1963-1994}

The concentration of Ghana's investment opportunities centred on few sectors of the economy before its independence in 1957; 23 primarily depending on export commodities like timber, cocoa, gold and other minerals. In 1943, the Tax Ordinance ${ }^{24}$ was passed that

17 ljeoma (n 16).

18 Nshimbi, Moyo and Oloruntoba (n 12).

19 Anon https://www.ecowas.int/about-ecowas/history/.

20 Nshimbi, Moyo and Oloruntoba (n 12)10.

21 Nshimbi, Moyo and Oloruntoba (n 12).

22 Ayangbah and Sun 2017 Cogent Social Sciences 1-22.

23 Dagbanja 2014 AJLS 253-292.

24 The Income Tax Ordinance No.27 of 1943.

60 || UCC Faculty of Law Journal 
offered tax breaks to investors as a way of encouraging and protecting investments and new ventures in line with the government's development agenda.

Under the First Republic, the Pioneer Industries and Companies Act of 1959 (PICA) was enacted to grant tax holidays to new ventures for a period of up to ten years. This benefitted registered companies that existed before 1950 which were given unimpeded guarantee to repatriate both their profits and capital any time. The Local Industries (Customs Duties Relief) Act of 1959 also enabled indigenous enterprises to benefit from exemptions on taxes that affected their import duties for manufacturing purposes. In an attempt to create a conducive legal regime to boast and safeguard foreign investments in the industry sector, the regime of Dr. Kwame Nkrumah enacted the Capital Investment Act (CIA) 1963 (Act 172) ${ }^{25}$ as well as the Companies Act, 1963 (Act 179). ${ }^{26}$ Whiles the Act 179 created a space for the growth of local industries, the Investment Promotion Board was put in place by the government to assist foreign companies to flourish in the country as part of its mandates. ${ }^{27}$ In the rebuilding effort of the government, it was considered prudent to have a legal environment that defused the adverse notion on the security and viability of private enterprises in the country, hence Act $172 .{ }^{28} \mathrm{~A}$ key feature of the CIA was the creation of the Capital Investment Board ( $\mathrm{CIB}$ ) as the regulatory agency to implement the mandates of Act $172 .{ }^{29}$ The CIB's responsibilities included; ${ }^{30}$

- to initiate and organise events to attract the investment of foreign capital,

- to give approval to applications for capital investments,

- to serve as liaison between government agencies and the investors, and

- to be responsible for the dissemination of information on foreign investment profile and recommend for who qualified for the grant of exemption, reduction, facility or licence as a business.

As stated earlier, the CIB was the regulatory institution which had a discretion to decide on the condition precedent for an agreement under the Act 172. Suffice to say that the Act 172 provided that for any foreign investment to be admitted into the country, it needed to be concurrently be regulated by the provisions of the Act 172 and an agreement which defined 25 After Independence from Britain in 1957, the Capital Investment Act 1963 (Act 172) was the first legislation in Ghana on investment drive.

26 As part of its objectives the Act 179 was enacted to create the conditions conducive for both African and foreign companies. This was the period recorded of influx of companies from countries such as South Africa to Ghana for commerce. See Commission of Enquiry "Final Report of the Working and Administration of the Present Company Law of Ghana 1963.

27 Dodoo "1980-981 Parliamentary Debates".

28 Parliamentary Debates" Session 1962-1963" 554.

29 Section 1(1) of the Capital Investment Act 172 of 1963.

30 Section 2(1) of the CIA. 
Towards a Conducive Investment Climate Within Ecowas: The Case for the Amendment of Sections 27 and 28 of the Ghana Investment Promotion Centre Act 865 of 2013

the conditions for admission and benefits to the investor. ${ }^{31}$

The essence of the agreement was to create an opportunity for the investor to negotiate for certain amenities, exemptions, interests and special dispensations which may not individually be catered for under the law. Conferring investor status on a foreign entity in the country required that the business viability was assessed by the state to fit into its own development agenda.

The overriding motivation that underpinned the Act 172 was to garner development and protect the public interest in all government's engagements with foreign investments..$^{32}$ It must be noted that Act 172 was not abrogated after the military takeover from the First Republic on 24 February 1966 led by Joseph Arthur Ankrah; neither was it repealed under the Dr. Kofi Abrefa Busia's government under the Second Republic, until the Capital Investment Decree,1973 (NLCD 141) ${ }^{33}$ came to repeal it under the military rule of Ignatius Kutu Acheampong.

The Second Republic (1969-1973), however, witnessed one of Ghana's restrictive investment climate to foreign businesses when the Alien Enterprises Licensing Regulations, 1970 (LI 670) was promulgated. ${ }^{34}$ The regulation conferred on the Minister responsible for Economic Planning, among far reaching regulations, the powers to restrict foreign sales agents. ${ }^{35}$ Not much in substance could be said as an addition to the content in the NLCD 141, except for the change in the name of the law to Capital Investment Decree. However, in 1975 a new decree, Investment Policy Decree 1975 (NRCD 329), came to repeal the NLCD 141.

On the assumption that previous governments had not been successful in their quests to attract the needed foreign investments, the Dr Hilla Limann's administration of the Third Republic enacted the Investment Code, 1981 (Act 437) to repeal the NRCD $329 .{ }^{36}$ The new law proceeded on the basis of;

- the absence of a consolidated piece of legislation that governed the generality of foreign investment activities in the country.

- a lack of a framework to assure investors of the security of their investment capital;

31 Section 2(3) of the CIA.

32 Dagbanja (n 23).

33 NLCD 141 came into force on 10 January 1973.

34 This was in pursuant to section 26 (1) of the Ghanaian Business (Promotion) Act 334 of 1970.

35 Regulation 1, L.I. 670 of 1970-Restriction on Foreign Sales Agents. A non-Ghanaian or alien enterprise shall not carry on business as an agent for the sale or promotion of the sale of any product or group of products of any principal not resident in Ghana unless such non-Ghanaian or alien enterprise is licensed by the Minister in accordance with these Regulations.

36 Section 50 of the Investment Act 437 of 1981.

62 || UCC Faculty of Law Journal 
- the prevailing non conducive economic and political milieu for private capital investment; and

- the lack of fiscal legal regime that provided an assurance for risks in productive sectors of the economy.

The objective of the Act 437 was to codify and merge all exiting legislations on investment preceding the administration of the Third Republic to among others; ${ }^{37}$

- redefine the areas and the extent to which non-Ghanaians were allowed to invest in Ghana,

- redefine priority areas of investment and conferring additional and wider range of benefits for investors, and

- to provide for various incentives and protections to foreign investors.

The focus on promoting indigenous Ghanaian investment interests culminated in the promulgation of the Ghanaian Business (Promotion) Act. ${ }^{38}$ It redefined and highlighted the areas where non-Ghanaians and Ghanaians were expected to invest. Pursuant to this objective, the Ghana Investment Centre (GIC) was birthed under Act 437 with the mandate to promote and regulate all investment activities in the country. ${ }^{39}$

The Provisional National Defence Council (PNDC) military rule under Flt. Lt. Jerry John Rawlings from 1983 saw Ghana through an International Monetary Fund programme, the Structural Adjustment Programme (SAP), ${ }^{40}$ which gave the country an opportunity to liberalise its economy for effective private sector participation in all sectors. To this end, the Act 437 was repealed by the Investment Code, 1985 (PNDCL 116), ${ }^{41}$ which identified businesses only allowed for Ghanaians to undertake and incentivised all investments that focused on key sectors of the economy. ${ }^{42}$ It must be noted that the GIC never ceased to exist under the new law of PNDCL $116 .{ }^{43}$ Again, the emphasis of this legal regime was centred on national development and public interest. Conditions precedent for registration of enterprises for the purposes of investment followed the same requirements under Act $437 .{ }^{44}$

37 Dodoo (n 27)1080.

38 Act 334 of 1970.

39 Sections 1(1) and 10(1) of Investment Act 437 of 1981.

40 Para. 3 of Preamble of Investment Act 437 of 1985; Ackah C, Adjasi C and Turkson F "Industrial Policy in Ghana: Its Evolution and Impact" 1-25.

41 Section 39(1) of Investment Code (PNDCL116) of 1985.

42 Section 12,16 and Schedule 5 of Investment Code (PNDCL116) of 1985.

43 Section 1(1) of Investment Code (PNDCL116) of 1985.

44 Sections 11(1) and 23 of Investment Act 437 of 1981. 
Towards a Conducive Investment Climate Within Ecowas: The Case for the Amendment of Sections 27 and 28 of the Ghana Investment Promotion Centre Act 865 of 2013

In all the legal provisions from 1963 to 1994, the meaning and scope of investment was restricted to assets-based projects. Portfolio investment ${ }^{45}$ was less contemplated under these regimes until the repeal of PNDCL 116 in 1994. All the incentives outlined and the programmes in that regard only benefitted the tangible investments.

\section{The liberal investment era 1994-2013}

In 1994, under the Fourth Republic, PNDCL 116 was replaced with the Ghana Investment Promotion Centre Act 478 of 1994 The Act 478 established the Ghana Investment Promotion Centre (GIPC) which replaced the GIC of 1985 under Act $172 .{ }^{46}$ The objective of Act 478 highlighted the encouragement, promotion and protection of various investments in the country. ${ }^{47}$

Unlike the investment requirements under the first phase, this regime required the satisfactory provision of a minimum capital to qualify as a foreign investor in Ghana. ${ }^{48}$ Additionally, the minimum capital under PNDCL 116 was reduced for the dispensation under the Act 478 with the view to reducing cost to encourage joint ventures between foreign investors and local entrepreneurs and enterprises that needed to rely on other expertise and technology. ${ }^{49}$ As part of the requirement for admission to invest capital in the economy under the former era, an investor( foreign or local) did not only need a certain capital but was also to satisfy conditions such as giving training to Ghanaian citizens, meeting some environmental control measures and making use of some amount of local raw material..$^{50}$ These criteria were missing from the requirements under Act 478 as a deregulatory measure to attract much investment. Of course, development cannot outlive its essence in investments but public interest was deemphasised under the Act 478 as the definition and content of investment shifted towards a theoretical leaning encompassing both direct and portfolio investments. ${ }^{51}$

In 2013, Ghana revised its investment law policy direction with the repeal of the Act 478 and

45 We take portfolio investments to mean investments in intangibles.

46 Section 1 of GIPCA of 1994.

47 Section 2(1) of GIPCA of 1994.

48 Section 19 of GIPCA of 1994.

49 Ghana Investments Promotion Bill: Memorandum (20 November 1993), 2. The capital requirement for joint business between Ghanaians and foreign investors under the PNDCL 116 was reduced from US\$ 60000 to US\$10 000. For ventures wholly owned by foreigners, the minimum capital was reduced to US\$ 50000 from US 100000 under the PNDCL 116 and US\$200 000 under the Investment Code (Amendment) Law, 1992 (PNDCL 292) under the GIPCA.

50 Section 23(2) of Investment Act 437 of 1981; Section 26(2) of Investment Code (PNDCL116) of 1985. 51 Section 40 of GIPCA.

64 || UCC Faculty of Law Journal 
passed the Ghana Investment Promotion Centre Act ,2013 (Act 865). This was attributed to the weaknesses identifies with the GIPCA..$^{52}$

It has been argued that some provisions in the current Act are incongruent with Ghana's investment treaty commitments because the legislature did not adequately contemplate standards required for consistent law with the country's treaty commitments. ${ }^{53}$

\section{The investment climate of Ghana today}

Ghana has remained stable with strong democratic governance system for over two decades since 1993, with progressive institutional and legislative credentials within sub-Saharan Africa. ${ }^{54}$ The effectiveness of key national legislations and institutional framework has served as impetus for the investor confidence Ghana enjoys..$^{55}$ Despite the challenges facing the economies of many developing countries, Ghana's own records with economic performance has been relatively superior to its contemporaries. ${ }^{56}$ Presently, the World Bank's Ease of Doing Business Report 2019 rates Ghana as the fastest growing economy in the world and the best place for doing business in West Africa. ${ }^{57}$

Generally the investment laws and regulations have been the basis for Ghana's relatively conducive investment environment in the subregion. ${ }^{58} \mathrm{As}$ expected, most of these laws have received amendments over the years to conform to the best international standards. The product of such reviews has resulted in the current GIPCA which came into force in 2013. The strengths of Ghana's investment environment depend largely on ACT 865 and other related legal arrangements in force. It is noted that:

First, the Act 865 provides guarantees that assure investors concerning prohibition against discrimination and expropriation..$^{59}$ Second, the Foreign Exchange Act, 2006 (Act 723) provides guarantee for unconditional transferability of profits for all enterprises freely in convertible currencies. Third, it is also important to underline that; Ghana belongs to

52 Para. 4 of Memorandum to Ghana Investment Promotion Centre Bill 2013.

53 Dagbanja (n 23).

54 Ayangbah and Sun (22).

55 GIPC date unknown https://www.gipcghana.com/invest-in-ghana/why-ghana.html.

56 Institute of Statistical, Social and Economic Research 2016 http://isser.edu.gh/index.php/sger.

57 The World Bank Ease of doing business Index https://data.worldbank.org/indicator/IC.BUS.EASE.

$\mathrm{XQ}$ ?locations=GH\&display=graph-- $\% 3 \mathrm{E}$.

58 Ayangbah and Sun (n 22).

59 Laws and Regulations date unknown Doing Business and Applicable Laws in Ghanahttps://www.

gipcghana.com/invest-in-ghana/doing-business-in-ghana/laws-regulation.html accessed 4 October 2019. 
the league of nations that have pledged to provide investment guarantees against noncommercial risks for investments in developing countries under the Multilateral Investment Guarantee Agency (MIGA) of the World Bank. ${ }^{60}$ Fourth, the investment environment in Ghana is further boosted with the government's signing on to the Bilateral Investment Promotion and Protection Agreements (IPPAs) and the number of Double Taxation Agreements $(D T A s){ }^{61}$ with some countries. ${ }^{62}$ And lastly, Ghana also has executed a number of (ratified and unratified bilateral) investment treaties with countries in the global North and South. So far, it is estimated that Ghana has executed over twenty-seven (27) of such BITs.

These are deliberate actions toward a secured and safer investment regime. ${ }^{63}$ However, it is observed that , in the current circumstances a further review of Act 865 is needed to promote a better condition for the country's international trade and investment relations.

\section{Review of the legal underpinning of Economic Community of West African States and its mandates}

The system of laws governing the structures of ECOWAS can be part of the international laws ${ }^{64}$ that regulates inter states relations. Per the par in parem non habet imperium rule, all member states under a treaty in international law have equal sovereignty which does not allow one to exercise any other power above the other(s). ${ }^{65} \mathrm{~A}$ treaty under international law is aimed at outlining a common force to bind on nations on their rights and obligations. ${ }^{66}$ According to Bennett and Strut, treaties "...are not, strictly speaking, sources of law."67 Whereas laws are made to be binding on its adherents, willy nilly, treaties only become as good as law when it receives consent of the promoters, ${ }^{68}$ which will receive the force of the maxim pacta sunt servanda. ${ }^{69}$ The nature of international relations have been such that treaties have evolved as the acceptable pacts for regulating rights and obligations of states in international law.

60 Laws and regulations ( 61 ).

61 Ghana has executed DTAs with countries like Belgium, Denmark, France, Germany, Italy, Netherlands, South Africa, Switzerland, United Kingdom(ratified) and Singapore (unratified). It is noteworthy that these agreements have no country from the ECOWAS subregion and in the larger African region except for South Africa(ratified) and Mauritius and Morocco (unratified).

62 Laws and regulations ( $\mathrm{n} 59$ ).

63 Laws and regulations ( $n 59$ ).

64 International law is defined as a system of rules governing relations among states; Bennett and Strug Introduction to International Law 1.

65 Bennett and Strug (n 64)15.

66 Bennett and Strug (n 64)12.

67 Bennett and Strug (n 64)12.

68 Bennett and Strug (n 64)12.

69 The agreement must be obeyed: This is the basic principle underlying treaties. 
In 1975, a 16 member-state agreed, under a multilateral treaty-The Economic Community of West African States (ECOWAS) Treaty to form the Economic Community of West African States. The treaty was signed in the Nigerian capital of Lagos on 28 May 1975 by all 16 heads of states of West African sovereign nations in SSA.

To meet the exigencies of the present world development order and aspirations of member states, the 1975 treaty was updated, accepted and executed by heads of states and governments of 15 countries (apart from Mauritius) ${ }^{70}$ in Cotonou, Benin Republic in July, 1993.

To commit the member countries to an enhanced regional economic bloc, the 93 articles of the new treaty demanded an agreement to those commitments in the signed treaty. It was to further bound the states to their obligations under the original 1975 treaty and review its successes. It is obvious to underline that; member states of ECOWAS are obliged under duty to renew commitments to seek the general economic and socio-political wellbeing of its members by accelerating its efforts through means that resonate with present development paradigms. The review of its treaty therefore was a genuine effort to this end. It is this commitment that we seek to emphasise as a responsible step towards the achievement of the laudable aspirations of the community. Underlying this consideration was the conviction that all steps to engendering economic development required a concerted and conscious effort by all states to harmonize their policies to make them a competitive block within the comity of nations. Another leg on which the review stood was the fact that,

the integration of the Member States into a viable regional Community may demand the partial and gradual pooling of national sovereignty to the Community within the context of a collective political will. ${ }^{71}$

The principal areas of operation of ECOWAS have been; ${ }^{72}$

- expanding the regional market;

- harmonising agricultural and industrial policies through production integration;

- ensuring the harmonious integration of physical infrastructures;

- promoting monetary and financial integration to facilitate trade;

- maintaining regional peace, stability, and security; and

- ensuring free movement of persons, including rights of residence and establishment.

It must be noted that despite the focus by the Community to facilitate rapid development

70 Mauritius has ceased to be a member of ECOWAS.

71 ECOWAS date unknown https://www.ecowas.int/ecowas-law/treaties/.

72 Aryeetey E "Regional Integration in West Africa, No. 170 Research programme on: Integration and

Co-operation in Sub-Saharan Africa" 20010ECD Development Centre Working Paper), 13-14. 
of cross boarder trading, the speed of the liberalisation process has been impeded by the unwillingness of states to adhere and fulfil their obligations under the elimination of key issues on tariff and non-tariff trade barriers. ${ }^{73}$

The Government of Ghana has consistently pledged its commitment to the implementation of the ECOWAS Protocol on Free Movement of Persons, Goods and Services, the Right of Residence and the Right of Establishment. ${ }^{74}$ This protocol is geared towards creating a single ECOWAS Regional Community to help remove all hindrances to free movement of people, goods, services and capital in the subregion. ${ }^{75}$ The objectives of the mechanisations is to "simplify and facilitate the movement and crossing of land borders and eliminate intermediate road side checks, delays and perceived illegal benefits; while ensuring the safety of people in a safe environment." ${ }^{76}$

\section{An assessment of the ECOWAS protocol on free movement of people and goods}

\section{A. The 1979 Protocol A/P.1/5/79 relating to Free Movement of Persons, Residence and Establishment}

This is the principal legal regime that concerns and is intended to give a practical meaning to the overall core objective of the ECOWAS as a regional body for the integration of its markets and people toward sustainable development. The mandates set in the Protocol are that it:

- Sets out right of Community citizens to enter, reside and establish in territory of member states as found under Art. 2(1).

- Establishes three-phased approach over 15 years to implementation of (i) right of entry and abolition of visas, (ii) residence and (iii) establishment; under Article 2.

73 Aryeetey (n 72) 22.

74 Ghana News Agency(GNA) 2017 https://www.tralac.org/news/article/12155-ghana-commits-to-ecowas-free-movement-protocol.html.

75 GNA ( $n$ 82); Ghana has moved on to inaugurate the National Steering Committee for the Regional Monitoring Mechanisms for Free Movement of Inter-State Passenger Vehicles, Persons and Goods within ECOWAS in 2017. This was organised within the framework of the ECOWAS-Swiss Agreement for the removal of harassment along ECOWAS highways and the joint ECOWAS EU funded $10^{\text {th }}$ European Development Fund (EDF) Project "Support to Free Movement of Persons and Migration in West Africa". Ghana was one of the eight countries (with Benin, Burkina Faso, Mali, the Ivory Coast, Niger, Nigeria and Togo) selected by the ECOWAS commission to pilot the national steering committee to operationalise the mechanism at the 46th Session of the Council of Ministers and 73rd Session of the Conference of Heads of States and Government.

76 GNA (n 74). 
- Conditions entitlement to enter territory of member state on possession of valid travel document and international health certificate in Article 3(1).

- Reserves right of member states to refuse admission into territory of Community citizens deemed inadmissible under domestic law as stated under Article 4.

- Establishes some requirements for expulsion under Article 11.

- Confirms that Protocol does not operate to detriment of more favourable provisions in other agreements concluded by member states as under Article 12.

The ECOWAS Protocol on the Free Movement of People and Goods entertains the free movement of citizens of member states within the Community. It confers on such citizens the right to enter and reside in the territory of any member state as long as such citizens had the requisite valid travel documents as required by the country applied to. ${ }^{77}$ It does not however, deny a member state to refuse the entry any such citizen on reasons under its own national laws. ${ }^{78} \mathrm{It}$ can be argued that the rationale for Article 3 is a natural response to a fundamental principle of international law and trade, known as national treatment which underpins almost every treaty across the world. ${ }^{79}$ National treatment requires that any time a nation confers any right on or gives any benefit or honour to its citizen, it is obliged to confer same to citizens of other states who reside and operate in that country. ${ }^{80}$

\section{B. The four supplementary protocols}

Between 1985 and 1990 four supplementary protocols have so far being adopted by the Community which committed member states to the following among other things:

- To make provision for valid travel document to their own citizens;

- To grant and facilitate Community citizens' right to apply to reside in the countries to seek and carry out income-earning employment;

- To ensure appropriate treatment for persons under expulsion from member states;

- To disallow the expulsion of Community citizens en bloc; and

- To limit the basis for individual to be expelled to reasons of national security, public order or morality, public health or non-fulfilment of a critical condition of residence.

771986 Supplementary Protocol A/SP.1/7/86 on the Second Phase (Right of Residence).

78 Right of Residence (n 77).

79 OECD 2004 OECD Working Papers on International Investment.

80 OECD 2004 Working Papers on International Investment. 
Towards a Conducive Investment Climate Within Ecowas: The Case for the Amendment of Sections 27 and 28 of the Ghana Investment Promotion Centre Act 865 of 2013

The objectives of the four individual supplementary protocols are set out as follows: ${ }^{81}$

1. 1985 Supplementary Protocol A/SP.1/7/85 on the Code of Conduct for the implementation of the Protocol on Free Movement of Persons, the Right of Residence and Establishment.

- Obliges member states to provide valid travel documents to their citizens.

- Establishes additional (to Article 11 of Protocol) requirements for treatment of persons being expelled (Article 4)

- Enumerates protections for illegal immigrants (Articles 5 and 7)

2. 1986 Supplementary Protocol A/SP.1/7/86 on the Second Phase (Right of Residence):

- Requires states to grant to Community citizens who are nationals of other member states "the right of residence in its territory for the purpose of seeking and carrying out income earning employment."

- Conditions entitlement to residence on possession of an ECOWAS Residence Card or Permit, and harmonization by member states of rules appertaining to the issuance of such cards/permits.

- Prohibits expulsion en bloc and limits grounds for individual expulsion to national security, public order or morality, public health, non-fulfillment of essential condition of residence.

- $\quad$ Stipulates equal treatment with nationals for migrant workers complying with the rules and regulations governing their residence in areas such as security of employment, participation in social and cultural activities, re-employment in certain cases of job loss and training.

3. 1989 Supplementary Protocol A/SP.1/6/89 amending and complementing the provisions of Article 7 of the Protocol on Free Movement, Right of Residence and Establishment:

- Amends provisions of Article 7 of Protocol to confirm obligation on signatories

81 Adepoju, Boulton and Levin 2010 Refugee Survey Quarterly 120-144. 
to resolve amicably disputes regarding the interpretation and application of the Protocol.

\section{1990 Supplementary Protocol A/SP.2/5/90 on the Implementation of the Third Phase (Right to Establishment):}

- Defines the right of establishment emphasizing non-discriminatory treatment of nationals and companies of other member states except as justified by exigencies of public order, security or health.

- Forbids the confiscation or expropriation of assets or capital on a discriminatory basis and requires fair and equitable compensation where such confiscation or expropriation.

\section{Analysis of sections 27 and 28, and challenges to the implementation of the Act 865}

As the analysis above has pointed us, a long journey has been taken both at the ECOWAS level and the national level regarding investment laws. Further as has been noted already, The Ghana Investment Promotion Centre Act 865 of 2013 was passed, in pursuance to article 36(4) of the Constitution, to replace the Ghana Investment Promotion Centre Act 478 of $1994 .{ }^{82}$ The provisions of Act 865 covers virtually everything on investment from the entry and admission of investors into any sector in Ghana; the protection of their investment and guarantees; employment; and their compliance to the laws of Ghana. ${ }^{83}$ The Act was further passed with an aim to further promoting and encouraging investment in the country. ${ }^{84} \mathrm{An}$ overview of the Act shows that it seeks to protect the foreign investor against discrimination under section 30 by granting the foreign investor, the employee or worker the same rights and obligations as local investors. ${ }^{85}$ This also includes the frowning on of special treatment given to prospective investors based on their nationality or country of origin. ${ }^{86} \mathrm{Also}$, the same laws that apply to domestic enterprises in similar enterprises in relation to licenses, permits, maintenance of books and records, insurances and taxes, are also applicable to the foreign investor ${ }^{87}$ The investor is further guaranteed under the act against the expropriation of his/ her investment wherein, expropriation can only ensue where it is in the national interest and made under a law which grants the investor a fair and adequate compensation and further

82 Section 44 of Act 865.

83 Some sectors such as Banking, insurance, fishing, securities, telecommunications, real estate, mining, oil, Gas, energy and the non-banking financial institutions have specific laws of which the investor must comply with when making investment into those fields.

84 Section 4 of Act 865.

85 Section 30(a) of Act 865.

86 Section 30(b) of Act 865.

87 Section 30(c) of Act 865. 
allows the investor the right to go to court for any determination in relation to the rights of the foreign investor or the compensation payable. ${ }^{88}$

Also, the foreign investor is guaranteed subject to the Foreign Exchange Act, 2006 (Act 723) and the Regulations and Notices issued under the Foreign Exchange Act, of an unconditional transferability in freely convertible currency of the dividends or net profit accruing from the investment, payments of loan servicing with respect to foreign loans which might have been obtained, fees and charges on technology transfer agreements and remittances, net of taxes and such amounts in the event the enterprise liquidates. ${ }^{89}$ Also under Section 33 of the GIPC Act 865, dispute resolution mechanisms are laid out to protect the investment of the investor. In order to prevent conflict of interests and to ensure there is a fair outcome in any dispute between the government and the investor, the act provides for a two staged dispute resolution approach. The foreign investor and the government, in the event of a dispute must first and fore-most attempt at settling the dispute amicably through a mutual discussion. ${ }^{90}$ Where the mutual settlement is not reached within six months of the negotiations, the party aggrieved may submit the matter for an arbitration in accordance with the procedures of the United Nations Commission of International Trade Law. ${ }^{91}$ Alternatively, and where there is a framework of any bilateral or multilateral agreement on investment protection to which the Government and the country of which the investor is a national are parties to, the investor may take advantage of it and submit the dispute in accordance with it. ${ }^{92}$ The parties are however not limited to any specific procedure of dispute resolution. The parties can agree on any specific dispute resolution mechanism they prefer where locally or internationally. ${ }^{93}$ Expatriate quotas are also afforded investors based on the amount of investment invested in the country. ${ }^{94}$

Generally, under the Act 865, investors are afforded a conducive climate to invest. The main challenge rests with the difference in treatment that lies between the Ghanaian investor and the foreign investor and that poses as a grave challenge in implementing the Act. We argue that, these restrictive provisions are afront to Ghana's commitment to the integration protocol of ECOWAS.

Notwithstanding the aim as stated in the Act, some authors have argued that the main aim 88 Section 31 of Act 865.

89 Section 32 of Act 865.

90 Section 33(1) of Act 865.

91 Section 33(2)(a) of Act 865 .

92 Section 33(2)(b) of Act 865.

93 Section 33(2)(c) of Act 865.

94 Section 35 of Act 865. 
of the promulgation of the Act was to protect the Ghanaian investor from unfair competition from foreign businessmen. ${ }^{95}$ This thus meant that the minimum capital requirements for investment by foreigners had to be increased. For instance, the minimum capital required to trade by foreigners under the Act was increased to $\$ 1$ million in cash or goods ${ }^{96}$ from $\$ 300,000$ under Act 478. Also, for foreigners to invest in any enterprise other than those reserved for Ghanaians or in a trading enterprise, the foreigner must do so with a Ghanaian having at least a $10 \%$ equity interest in the joint investment/enterprise and must have at least a foreign capital of not less than two hundred thousand United States dollars in cash or capital goods relevant to the investment or a combination of both. ${ }^{97}$ Alternatively, when the foreign investor chooses to invest alone without the $\$ 500,000$ in cash or capital goods relevant to the investment or a combination of both by way of equity capital in the enterprise. ${ }^{98}$

Looking at the onerous capital requirements differently, it is still observed that the Act seeks to encourage the foreigners to engage in large scale investment and trading in order to protect the petty trading activities of Ghanaians and rightly so, the Act under section 27 reserves some activities for only Ghanaian owned enterprises. Under section 27, foreign investors cannot channel their investments into areas like taxi operation, ${ }^{99}$ beauty and barbering salon operation, ${ }^{100}$ stationery and book printing, ${ }^{101}$ the printing of recharge cards ${ }^{102}$ and some other more.

\section{Establlishing the conflict of Sections 27 and 28 of 865 with the Freedom of Establishment under ECOWAS Protocols on Free Movement}

The revised Treaty of the Economic Community of West African States (ECOWAS)

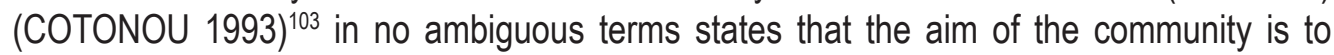
promote cooperation and integration amongst its members so as to lead to the eventual establishment of an economic union in West Africa. The long-term aim of that is to see to the increase in the standards of the people in West Africa as well as to maintain economic stability and good relation amongst the members. To be able to realise this aim, the member states agreed on some practical measures and notable amongst them is that the member 95 Quartey $2013 \mathrm{https}: / / w w w . t h e a f r i c a r e p o r t . c o m / 5512 / g h a n a-r e v i s e s-i n v e s t m e n t-l a w s-t o-s a f e g u a r d-$ local-traders/.

96 Section 28(2) of Act 865.

97 Section 28(1)(a) of Act 865.

98 Section 28(1)(b) of Act 865.

99 Section 27 (b) of Act 865.

100 Section 27 (c) of Act 865.

101 Section $27(e)$ of Act 865.

102 Section 27 (d) of Act 865.

103 Article 3(1) of the revised Treaty of the Economic Community of West African States (ECOWAS) of 1993 (COTONOU 1993). 
states are to ensure there is an establishment of a common market through "the removal, between Member States, of obstacles to the free movement of persons, goods, service and capital, and to the right of residence and establishment." 104

Moreover, and more recently, under the Protocol to the Treaty Establishing the African Economic Community Relating to the Free Movement of Persons, Right of Residence and Right of Establishment, under article 17, the right to establishment is recognised wherein member states are given the right of establishment in other member countries. The right of establishment defined there includes the right to set up one's trade or profession or vocation or any economic activity as a self-employed person.

The right to establishment is defined under Supplementary Protocol A/Sp.2/5/90 of the ECOWAS as

the right granted to a citizen who is a national of the Member State to settle or establish in another Member State other than his State of Origin, and to have access to economic activities, to carry out these activities as well as to set up and manage enterprises, and in particular companies, under the same conditions as defined by the legislation of the host Member State for its own nationals. ${ }^{105}$ (Emphasis are ours).

Thus, pursuant to the freedom of establishment, a national of a member of the community has the right to establish his/her business in the territory of another member country in accordance with the laws of that country without discrimination as being a "foreigner". Rightly so, article 4 of the protocol prohibits any form of discrimination to non-nationals. Thus, the states must accord the same treatment to non-nationals as it does to its own national. The state is only given the leeway to create a differential treatment in relation to a specific activity. With that, the state must indicate such activity to the Executive Secretariat. ${ }^{106}$ Further under article 12 of the Supplementary protocol, there is a duty on member states to eliminate all forms of administrative procedures as well as internal laws (and this applies to any sector in the economy) which may serve as an impediment to the freedom of establishment. ${ }^{107}$

With the freedom of establishment in mind, vis a vis Sections 27 and 28 of the GIPC Act 865, an apparent conflict in law is evident. The reserve of some economic activities under section 27 for only Ghanaians seem as nothing but a protectionist measure. The provisions of the Ecowas Protocols prohibit such a conduct. All member states under the ECOWAS pledged to 104 Article 3(2)(D)(iii) of COTONOU 1993.

105 Article 1 of the Supplementary Protocol A/Sp.2/5/90 on the Implementation of the Third Phase (Right of Establishment) of the Protocol on Free Movement of Persons, Right of Residence and Establishment. 106 Article 4(2) of the Supplementary Protocol A/Sp.2/5/90.

107 Article 12(2) \& (5) of the Supplementary Protocol A/Sp.2/5/90.

74 || UCC Faculty of Law Journal 
ensure economic integration amongst the member states. They pledged to support economic coexistence of which such discrimination as done under article 27 of the current GIPC Act was not contemplated. Further, the minimum capital requirements under article 28 of the Act 865 is also nothing but onerous which is also construed as a protectionist measure to secure the investments for the locals. Since there is a prohibition on treating nationals different from non-nationals under the ECOWAS protocols, if the government of Ghana seeks to impose such hefty amounts as minimum capital requirements before investing by foreigners, then it must be same for the locals too. Anything short of it may amount to discrimination of which violates the freedom of establishment.

\section{Conclusion}

Investors have a key role in the management of the affairs of such investments anywhere. It has been established that a more secured avenue for financing economic growth and progress is through the means of FDI than through multinational ${ }^{108}$ aid or loans. ${ }^{109}$ One means to accelerate economic growth for poor nations is by means of increased capital injections into such economies by FDls. ${ }^{110}$

As discussed in this paper, the Ghanaian investment regime has taken on different phases over the years. It has also been shown that the investment laws in Ghana have a history and it is from that history that many of the current laws have evolved from. Investors enjoy protection under the investment regime from such Acts as expropriation and dispute settlement. The current outstanding de merit with the investment laws as identified in this article has been the protectionist measure, rather than the desired liberalisation, as has been adopted by sections 27 and 28 of Act 865 . It has been shown that the said sections contravene the ECOWAS protocols on the free movement of people, more specifically the Supplementary Protocol A/Sp.2/5/90 of the ECOWAS.

There is no reason in allowing for such explicit contravention of the Ghanaian laws with the ECOWAS laws especially when the contravention causes mayhem and a lack of implementation. It is settled that international treaty agreements requires a country to conform to it with its municipal laws. As nationals of the ECOWAS countries are allowed free movement across the member states, freedom must also be granted them to find work that suit their skills so as to prevent them from becoming a liability in the country by being unemployed. If the country will also see more investments, then the capital requirements for foreigner investors must not be employed as a protectionist measure.

108 Example is the international Monetary Fund aid. See also Bradlow 2018 IORJ 213-236.

109 Moyo Dead Aid: Why Aid is Not Working and How There is a Better Way for Africa.; UNCTAD 2011 https:// www.unctad-docs.org/files/ UNCTAD-WIR2011-Full-en.pdf.

110 Hunter Jr. 2003 Oklahoma City University Law Review 28-851. 
Amendments of sections 27 and 28 of Act 865 are therefore in order to the extent that it will intersect with Ghana's commitments to its obligation as a signatory to the ECOWAS protocol. As a key voice for economic transformation of the sub-region, Ghana must take the lead to transform its investment environment through a progressive legal environment that conforms to every protocol it has ratified in the ECOWAS subregion. The provisions of the Act 865 have to respond to the growing importance of market integration and both intra and international commerce. Global markets phenomenon requires concerted efforts at integrating smaller markets to compete favourably on the world stage. This throws a daunting challenge to developing economies such as Ghana and its neighbours to look beyond their respective domestic laws and concentrate on building interconnectedness in trade and investment opportunities to that effect to achieve integration. 


\section{References}

Ackah C, Adjasi C and Turkson F "Industrial Policy in Ghana: Its Evolution and Impact" 1-25 at 2 in Newman C, Page J and Rand J (eds.) Manufacturing Transformation: Comparative Studies of Industrial Development in Africa and Emerging Asia (Oxford University Press 2019)

Adepoju A, Boulton A and Levin M 2010 "Promoting Integration Through Mobility: Free Movement Under ECOWAS" Refugee Survey Quarterly 120-144

Aryeetey E "Regional Integration in West Africa, No. 170 Research programme on: Integration and Co-operation in Sub-Saharan Africa" 20010ECD Development Centre Working Paper)1-45

Ayangbah A and Sun L "Comparative Study of Foreign Investment Laws: The Case of China and Ghana" 2017Cogent Social Sciences 1-22

Bennett TW and Strug J Introduction to International Law (Juta and Co. Ltd 2013)

Bradlow DD "Assessing the Potential for Global Economic Governance Reform" 2018 IORJ 213-236

Dagbanja DN "The Changing Pattern and Future of Foreign Investment Law and Policy in Ghana: The Role of Investment Promotion and Protection Agreements" 2014 AJLS 253-292

Dodoo SO (ed.) Parliamentary Debates: Second Session of the First Parliament of the Third Republic of Ghana - Second Year of the Third Republic (1980-1981 Session, 29 April 1981-21 August 1981)

Hunter RJ Jr. "Legal Considerations in Foreign Direct Investment" 2003 Oklahoma City University Law Review 28-851

ljeoma EO "Evaluating Development Projects and Programmes in Africa The Case of the New Partnership for Africa's Development (NEPAD)" 2007 Africa Insight 62

Kolovos AE "Regional Integration in East Asia" Poland State University

Moyo D Dead Aid: Why Aid is Not Working and How There is a Better Way for Africa (London: Macmillan 2009)

Nshimbi CC, Moyo I and Oloruntoba SO "Borders, Informal Cross-Border Economies and Regional Integration in Africa An Introduction" 2018 Africa insight 4 
Towards a Conducive Investment Climate Within Ecowas: The Case for the Amendment of Sections 27 and 28 of the Ghana Investment Promotion Centre Act 865 of 2013

OECD Most-Favoured-Nation Treatment in International Investment Law, 2004 OECD Working Papers on International Investment

Opanike A and Aduloju AA "ECOWAS Protocol on Free Movement and Trans-border Security in West Africa" 2015 J. Civil and Legal Sciences 154

Parliamentary Debates "Third Session of the First Parliament of the Republic of Ghana Third Year of the Republic" (Government Printing, Accra, Session 1962-1963, 26 February- 5 April 1963) 554

Sanusi H and Adu-Gyamfi S "Ghana's Foreign Policy: Some Regional and National Interests" 2017 Journal of Human Sciences 599-608

UNCTAD "World Investment Report 2011, U.N. Sales No. E.11. II. D.2." 2011 http:// www. unctad-docs.org/files/ UNCTAD-WIR2011-Full-en.pdf accessed 25 September 2019

\section{Legislation}

1992 Constitution of the Republic of Ghana

Alien Enterprises Licensing Regulations (LI 670) of 1970

Ghana Investment Promotion Centre Act 478 of 1994

Ghana Investments Promotion Bill: Memorandum (20 November 1993) 2

Ghana Investment Promotion Centre Act 865 of 2013

Ghanaian Business (Promotion) Act 334 of 1970

Capital Investment Act 172 of 1963

Capital Investment Decree (NLCD 141) of 1973

Investment Code (Act 437) of 1981

Investment Code (PNDCL116) of 1985

The Income Tax Ordinance No.27 of 1943

\section{International instruments}

African Charter on Human and Peoples' Rights, adopted by the Organisation of African Unity in Nairobi on 27 June 1981, OAU Doc CAB/LEG/67/3 rev.5; 1520 UNTS 217 1986 Supplementary Protocol A/SP.1/7/86 on the Second Phase (Right of Residence)

Supplementary Protocol A/Sp.2/5/90 on the Implementation of the Third Phase (Right of 
Establishment) of the Protocol on Free Movement of Persons, Right of Residence and Establishment

\section{Internet sources}

BBC 2019 Unknown Men Take Force Lock Up Nigerian Shops for Ghana

https://www.bbc.com/pidgin/tori-48682143 accessed 28 October 2019 accessed 28 October 2019

Cuyvers A date unknown Freedom of Establishment and the Freedom to Provide Services in the EU https://openaccess.leidenuniv.n//bitstream/handle/1887/58828/ Freedom_of_Establishment_and_the_Freedom_to_Provide_Services_in_the EU.pdf?sequence=1 accessed 23 November 2019

ECOWAS date unknown From an ECOWAS of States to an ECOWAS of People, Treaty, https://www.ecowas.int/ecowas-law/treaties/ accessed 28 September 2109

ECOWAS date unknown Supplementary Acts/Protocols/ Decisions: Official Journal https:// www.ecowas.int/ecowas-law/find-legislation/ accessed 28 September 2109

Ghana News Agency 2017 Ghana Commits to ECOWAS Free Movement Protocol https:// www.tralac.org/news/article/12155-ghana-commits-to-ecowas-free-movementprotocol.html accessed 21 September 2019

GhanaWeb 2019 Nigeria's Borders to Remain Closed Until End of January https://www. ghanaweb.com/GhanaHomePage/NewsArchive/Nigeria-s-borders-to-remainclosed-until-end-of-January-795921 accessed 27 October 2019 accessed 28 October 2019

GHOne TV 2019 GUTA Clashes With Nigerian Traders Association In Ghana Over Trade Tiff: Nigerian Traders Seek Review Of GIPC Act 865 https://www.facebook. com/156439147743926/posts/257668286320988 accessed 30 November 2019

GIPC date unknown Invest in Ghana https://www.gipcghana.com/invest-in-ghana/whyghana.html accessed 12 October 2019

Institute of Statistical, Social and Economic Research 2016 The state of the Ghana Economic Report 2016 http://isser.edu.gh/index.php/sger accessed 17 April 2019

Laws and Regulations date unknown Doing Business and Applicable Laws in Ghanahttps:// www.gipcghana.com/invest-in-ghana/doing-business-in-ghana/laws-regulation. 
Towards a Conducive Investment Climate Within Ecowas: The Case for the Amendment of Sections 27 and 28 of the Ghana Investment Promotion Centre Act 865 of 2013

html accessed 4 October 2019

Quartey L 2013 Ghana revises investment laws to safeguard local traders https://www. theafricareport.com/5512/ghana-revises-investment-laws-to-safeguard-localtraders/ accessed 20 November 2019

rfi 2019 Nigerian-Owned Shops in Ghana Forced to Close by Traders: Union http://www.rfi. fr/en/africa/20191101-nigerian-owned-shops-ghana-kumasi-forced-close-tradersunion-borders-closed accessed 28 October 2019

https://www.ecowas.int/about-ecowas/history/ accessed on 15 September 2019 